\title{
RETHINKING SUBSIDIARITY AND THE BALANCE OF POWERS IN THE EU IN LIGHT OF THE LISBON TREATY AND BEYOND
}

\begin{abstract}
Simona Constantin*
Summary: The principle of subsidiarity is meant to demarcate the exercise of competences between the EU and its Member States and to balance the claim for regulatory power which these two legal worlds make. This article takes the view that subsidiarity has not proven so far to be a very useful touchstone in this regard. Moreover, there are still shortcomings in its envisaged application based on the legal framework provided by the Lisbon Treaty. It is therefore suggested that an approach beyond subsidiarity should be taken in future research in order to shed more light on how powers are balanced in practice in the EU. This approach submits for exploration the following hypothesis: the competences between the EU and its Member States are demarcated in daily practice by negotiating and balancing national discretionary powers, rather than defined through the legal framework and application of subsidiarity. In this view, two paths of research are proposed. The first identifies the Council, more specifically its de facto decision-making body, the Committee of Permanent Representatives (Coreper), as an arena for using Member States national discretionary powers in the process of negotiating legislation at the ex ante EU law-making level. The second view suggests an analysis of how the powers are balanced at the ex post law-making level by the European Court of Justice (ECJ) when assessing the principle of proportionality and thereof the margin of discretion left to the Member States in protecting their national powers and interests. These two specific perspectives are to be placed in the broader perspective of achieving national interests while still contributing to the unity of EU law-making.
\end{abstract}

\section{Introduction}

The traditional understanding of the legal interplay between the EU and its Member States is substantiated in terms of attributing and divid-

\footnotetext{
PhD candidate (Tilburg University), LLM (University of Amsterdam), The Netherlands. Parts of this article present ideas contained in the $\mathrm{PhD}$ proposal entitled 'Beyond Subsidiarity. Negotiating and Balancing National Discretionary Powers in the EU'. The author is grateful to Professor Linda Senden and Professor Bert van Roermund for their comments on some ideas expressed in this article.
} 
ing competences. Attribution and subsidiarity therefore play an instrumental role in this regard. The principle of subsidiarity was included as a guiding principle of the European Union (EU) in the Treaty of Maastricht. Since then, increasing attention has been given to subsidiarity, both in formal aspects - treaty amendments shaping its legal framework, and informal practices - interinstitutional agreements and culture developed by the EU institutions. As read in Article 5 of the Treaty establishing the European Community (EC Treaty), the role attributed to subsidiarity is to regulate the exercise of competences between the EU and the Member States and to balance the claim for regulatory powers which these two legal worlds make. Over time, the meaning of subsidiarity has triggered many analyses. ${ }^{1}$ The main stance taken in legal literature underlines that it is hard to clearly operationalise and scrutinise subsidiarity. Due to its narrow legal dimension, the decision on who should do what in the EU is ultimately left to the political arena. Moreover, although when it became part of the Union's framework subsidiarity was perceived as a protection against the overwhelming EU legislation, since Maastricht the integration process has entered into new areas of policy, with more aspects being regulated at EU level or touched upon by EU legislation. ${ }^{2}$ It is in this context that it appears relevant to ask whether the principle of subsidiarity is well suited and sufficient for the protection of national powers, and whether it provides understanding on how the powers are balanced in practice between these two legal worlds: the EU and its Member States. Several aspects complicate this understanding and they can be broadly encapsulated in three lines of vision. Firstly, there is the limited and vague phrasing of the legal framework of subsidiarity. Secondly, there are the two common perspectives attached to it: legal and political. And thirdly, there are the two rationales underlying its function: according to one, subsidiarity functions as a shield against EU powers, while according to the other it functions as a dynamic principle, a double-edged sword which the two legal worlds can use when it seems to fit the political bill.

\footnotetext{
1 Legal literature abounds in discussions on subsidiarity. For references, see the subsidiarity library of the Committee of the Regions at <http://cor.europa.eu/subsidinet/en/sublibrary.htm> accessed 30 March 2008 and the literature referred to in this article.

2 Under the first pillar, the Community's pillar, the development of the internal market has touched upon areas of policy which fall under the competence of the Member States, the EU having only coordinating competence (eg health, industry; culture, tourism, education, vocational training; youth and sport). In this line, the current Review of the Internal Market Package of the European Commission takes a new perspective, where the internal market 'goes hand-in-hand with social and environment policies to contribute to sustainable development goals.' See Commission (EC), 'A single market for 21st century Europe' (Communication) COM (2007) 725, 20 November 2007

<http://eur-lex.europa.eu/LexUriServ/LexUriServ.do?uri=CELEX:52007DC0724:EN: NOT> accessed 30 March 2008. The developments under the second and third pillars have also contributed to the expansion of the EU integration process.
} 
Although these visions on subsidiarity up to now position the principle as a tool to demarcate between European and national competences, they are rather theoretical and create a top-down approach in understanding how competences are employed in the EU law-making process. Based on a detailed overview of the principle of subsidiarity in retrospect and in light of the Lisbon Treaty, this article takes the view that no matter which of these visions is upheld, subsidiarity is not a very useful touchstone for assessing the actual exercise of powers in the EU. Rather, the article proposes a bottom-up perspective for future research on the subject, which could focus more on the process taking place beyond the legal framework of subsidiarity. The following hypothesis will therefore be put forward: the competences between the EU and the Member States are demarcated in daily practice by negotiating and balancing national discretionary powers, rather than defined through the legal framework and application of subsidiarity. In this view, three perspectives will be proposed for exploration. The first identifies the Council, more specifically its de facto decision-making body, the Committee of Permanent Representatives (Coreper), as an arena for using Member States' national discretionary powers in the process of negotiating legislation at the ex ante EU law-making level. The second one proposes an analysis of how the powers are balanced at the ex post law-making level by the European Court of Justice (ECJ) when assessing the principle of proportionality and thereof the margin of discretion left to the Member States in protecting their national powers and interests. These two specific perspectives are to be underlined by a third perspective which will employ the concepts of discretion, interests and unity. More specifically, future research would aim to analyse the ways in which Member States can protect national interests through the use of discretionary powers in daily practice in the framework of EU lawmaking unity.

It is not the ambit of this article to engage in an extensive analysis of the principle of subsidiarity. Nevertheless, in the present context, when subsidiarity seems to be upgraded in the public debate and in the legal construction of the EU, a detailed overview is needed in order to explain why this article ultimately proposes an approach beyond subsidiarity. This overview will present how the principle has been legally construed and applied so far, and will assess whether it can strike the right balance between the EU and its Member States. The focus will be to show that the existence of subsidiarity up to now in the life of the EU, as well as the envisaged application of the new legal framework provided by the Lisbon Treaty, does not offer a sufficiently clear picture of the way in which the powers between the EU and the Member States are balanced in practice. In this context, it will be pertinent to propose that an approach beyond subsidiarity could be taken in future research. This analysis will unfold in three further parts of this paper. Part 2 presents an overview of sub- 
sidiarity, starting with a retrospective, delving into the relevant novelties contained in the Lisbon Treaty, and ending with concluding remarks. The bottom-up perspective that goes beyond subsidiarity and which is proposed for future research will be put forward in part 3, followed by conclusions in part 4.

\section{On subsidiarity}

\subsection{Subsidiarity in retrospect}

\subsubsection{Legal framework}

The legal framework of the principle of subsidiarity has been gradually construed within the treaties. There was no mention of the principle in the initial treaties. ${ }^{3}$ Only with the adoption of the Single European Act was subsidiarity mentioned in a treaty text, although it targeted one field only $Đ$ environment protection. ${ }^{4}$ The explicit introduction of subsidiarity as a general principle of the EU took place with the Treaty of Maastricht. Referred to even in the preamble, ${ }^{5}$ the principle was stated in Article $\mathrm{B}^{6}$ and defined in Article 3b (now Article 5) of the Treaty establishing the European Community (EC Treaty). ${ }^{7}$ A Protocol on the Application of the Principles of Subsidiarity and Proportionality was attached to the Treaty

\footnotetext{
3 Nevertheless, it can be said that some germs of the principle already existed, as Article 5 of the Treaty establishing the European Coal and Steel Community (ECSC Treaty) provided that the Community will 'assure the establishment, the maintenance and the observance of normal conditions of competition and take direct action with respect to production and the operation of the market only when circumstances make it absolutely necessary' (emphasis added). Later on, Article 235 (now Article 308 EC) of the Treaty establishing the European Economic Community (EEC Treaty) contained a rather implicit reference to subsidiarity providing that: 'If any action by the Community appears necessary to achieve, in the functioning of the Common Market, one of the aims of the Community in cases where this Treaty has not provided for the requisite powers of action, the Council, acting by means of a unanimous vote on a proposal of the Commission and after the Assembly has been consulted, shall enact the appropriate provisions' (emphasis added).

4 Article 130-R (4) provided that 'the Community shall take action relating to the environment to the extent to which the objectives referred to in paragraph 1 can be attained better at Community level than at the level of the individual member states.'

5 'RESOLVED to continue the process of creating an ever closer union among the peoples of Europe, in which decisions are taken as closely as possible to the citizen in accordance with the principle of subsidiarity.'

6 The last paragraph of this article states: 'The objectives of the Union shall be achieved as provided in this Treaty and in accordance with the conditions and the timetable set out therein while respecting the principle of subsidiarity as defined in Article $3 b$ of the Treaty establishing the European Community.'

7 This article provides: 'In areas which do not fall within its exclusive competence, the Community shall take action, in accordance with the principle of subsidiarity, only if and in so far as the objectives of the proposed action cannot be sufficiently achieved by the Member States and can therefore, by reason of the scale or effects of the proposed action, be better achieved by the Community.'
} 
of Amsterdam. This protocol was based on the conclusions of the European Council of Birmingham from 16 October 1992 and the European Council of Edinburgh from 11-12 December $1992,{ }^{8}$ and on the Inter-Institutional Agreement of 25 October 1993 between the Parliament, the Council and the Commission on the procedures for implementing the principle of subsidiarity. ${ }^{9}$ The protocol requires the institutions to take account of the principle of subsidiarity when exercising their powers, and provides several procedural requirements, targeting especially the Commission. ${ }^{10}$ It also provides guidelines for assessing when a Community action is justified ${ }^{11}$ and incorporates the position taken in the conclusions of the Edinburgh European Council, namely that subsidiarity is a dynamic concept ${ }^{12}$ (emphasis added). Finally, the Constitutional Treaty meant to reform the legal framework and to increase the scrutiny for EU legislation compliance with subsidiarity. The main novelty thereof was the introduction of a new actor: the national parliaments. As these provisions have been carried on in the present Lisbon Treaty, we will delve into their analysis in section 2.2 of this article.

It can be observed that the legal framework of subsidiarity developed along with the increase through various treaty amendments of the competences regulated at EU level. ${ }^{13}$ The more competences were transferred to the Union, the more developed became the legal framework of the principle of subsidiarity. Despite this, as will be further discussed, the present and the future legal frameworks of subsidiarity in the Lisbon

\footnotetext{
8 See Annex 1 to Part A of the Presidency Conclusions: Bull EC 12-1992, 13.

9 Bull EC 10-1993, 128.

10 According to Article 9 of the Protocol, in exercising its right of initiative, the Commission should hold mandatory hearings, provide explanatory memorandums, take account of financial and administrative burdens, and present annual reports to the other institutions, respectively, the Council and the European Parliament, and to the European Council, as well as to the Committee of Regions and the Economic and Social Committee.

11 Article 5 of the Protocol provides the following guidelines: '- the issue under consideration has transnational aspects which cannot be satisfactorily regulated by action by Member States; - actions by Member States alone or lack of Community action would conflict with the requirements of the Treaty (such as the need to correct distortion of competition or avoid disguised restrictions on trade or strengthen economic and social cohesion) or would otherwise significantly damage Member States' interests; - action at Community level would produce clear benefits by reason of its scale or effects compared with action at the level of the Member States.'

12 Article 3 of the protocol provides: 'Subsidiarity is a dynamic concept and should be applied in the light of the objectives set out in the Treaty. It allows Community action within the limits of its powers to be expanded where circumstances so require, and conversely, to be restricted or discontinued where it is no longer justified.'

13 Several elements have been identified as having created the context for the rise of subsidiarity; broadly, they relate to the constitutional development of the EU due to the ECJ's bold approach in this sense and to the widening of Community's powers. See GA Bermann, 'Taking Subsidiarity Seriously: Federalism in the European Community and the United States' [1994] Columbia L Rev 348-66.
} 
Treaty contain shortcomings and do not shed light on how the powers are balanced in practice between the EU and its Member States.

\subsubsection{Interpretation in literature}

Since Maastricht, the meaning of subsidiarity has attracted a lot of academic attention. ${ }^{14}$ The relevant literature is abundant in considerations, and the principle has been analysed within various policy areas. ${ }^{15}$ Three main lines of vision can be identified in legal literature. The first highlights the limited and vague phrasing of the legal framework of subsidiarity. The tensioned political spirits surrounding the adoption of the Maastricht Treaty was seen as an explanation of the deficiencies and ambiguity of the definition of subsidiarity. ${ }^{16}$ The principle is stated in Article 5, para (2) EC which flanks subsidiarity with the principle of attribution $Đ$ para (1) and the principle of proportionality Đ para (3). ${ }^{17}$ In the wording of this article, attribution generally limits Community action to the competences which have been transferred from the Member States, and subsidiarity concerns the exercise of action in the area of shared competences, while proportionality applies to overall Community actions. All three principles play a role in delimiting the space for action between the Community and the Member States. As read in this definition, subsidiarity was intended to control the exercise of the regulatory powers in those policy areas where the Union had no exclusive competence, and its in-depth significance relates to the fact that decisions should be taken as

14 On its origins and interpretation in a broader sense, see V Constantinesco, 'La Subsidiarité comme Principe Constitutionnel de l'Intégration Européenne' (1991) 46 Aussenwirtschaft 439-59; G de Burca, 'Re-appraising Subsidiarity's Significance after Amsterdam' (1999) Harvard Jean Monnet Working Paper, No. 7/1999<http://www.jeanmonnetprogram.org/papers/99/990701.html> accessed 30 March 2008; NW Barber, 'The Limited Modesty of Subsidiarity' (2005) 11 ELR 308Đ25; J Peterson, 'Subsidiarity: A definition to Suit Any Vision?' (1994) 47 Parliamentary Affaires 116-32; A Føllesdal, 'Subsidiarity’ (1998) 6 Journal of Political Philosophy 190-218; Y Soudan, 'Subsidiarity and Community in Europe' (1998) 5 Ethical Perspectives 177-87; N Emiliou, 'Subsidiarity: An Effective Barrier Against the Enterprises of Ambition' (1992) 17 EL Rev 383-407.

15 On specific policy area analysis, see the literature cited in G de Burca, 'Proportionality and Subsidiarity as General Principles of Law' in U Bernitz and J Nergelius (eds), The General Principles of EC Law (Kluwer Law International, The Hague 2000) n 23.

16 See discussion in A Estella, The EU Principle of Subsidiarity and its Critique (OUP, Oxford 2002) 82-89.

17 Article 5 EC: 'The Community shall act within the limits of the powers conferred upon it by this Treaty and of the objectives assigned to it therein. In areas which do not fall within its exclusive competence, the Community shall take action, in accordance with the principle of subsidiarity, only if and in so far as the objectives of the proposed action cannot be sufficiently achieved by the Member States and can therefore, by reason of the scale or effects of the proposed action, be better achieved by the Community. Any action by the Community shall not go beyond what is necessary to achieve the objectives of this Treaty.' 
close as possible to the citizens. ${ }^{18}$ The fact that the EC and EU Treaties do not include a precise demarcation of the shared competences blurs the margins of application of the principle of subsidiarity, as both the EU and the Member States claim regulatory powers. ${ }^{19}$ It can be said that the way in which some of the Treaty provisions are phrased limits the regulatory powers of the Member States, as they predetermine an EU action. ${ }^{20}$ From its definition, it is understood that the objectives of the envisaged measure play an important role. For several of these objectives, Community actions are already envisaged, while, for others, arguments could be made for both Community and Member State action. ${ }^{21}$ In practice, it is difficult to make such assessments. The guidelines included in the Amsterdam Protocol shed limited light in this respect. ${ }^{22}$ However, it is true that $a$ priori clear and strict criteria for implementing subsidiarity would be hard to define. This is due on one hand to the interdependencies between EU policies which form a basis for motivating the necessity of a particular Community intervention, ${ }^{23}$ and on the other hand to the fact that decisions are based on analyses of specific resource contexts, which might change over time. Thus, as already acknowledged in the literature, the application of subsidiarity is to be considered rather on a case-bycase basis. $^{24}$

The second line of vision in the literature refers to the fact that most common approaches to subsidiarity study the principle from a legal and political perspective; although its mainly political character is highlighted, there is no common view on how much of a legal principle it is. ${ }^{25}$ After its entering into force, subsidiarity was perceived in the literature

\footnotetext{
18 This is stated in Article 1 of the Treaty on the European Union (EU Treaty): 'This Treaty marks a new stage in the process of creating an ever closer union among the peoples of Europe, in which decisions are taken as openly as possible and as closely as possible to the citizen.'

19 On the vertical order of competences of the EU, an in-depth analysis is presented in A von Bogdandy, J Bast, 'The European Union's Vertical Order of Competences: the Current Law and Proposals for its Reform' (2002) 39 CML Rev 227-68.

20 This, for example, is the case with Articles 95 and 308 EC which have been extensively used and interpreted in the past, especially as regards the establishment and functioning of the internal market. See, for example, S Crosby, 'The New Tobacco Control Directive: An Illiberal and Illegal Disdain for the Law' (2002) 27 EL Rev 177-93 and R Schuetze, 'Dynamic Integration $\mathrm{Ð}$ Article $308 \mathrm{EC}$ and Legislation 'in the Course of the Operation of the Common Market': A review Essay', (2003) 23 Oxford J Legal Stud 333-44.

21 See examples in Estella (n 16) 106-14.

22 See $\mathrm{n} 11$.

${ }^{23}$ This is the case of the internal market which, being placed at the core of EU policies, has touched upon other areas which fall in the powers of the Member States. See n 2.

24 See de Burca (n 14) 25.

25 This relates in great measure to the limits of judicial review applied by the ECJ when assessing subsidiarity. These aspects will be presented in sub-section 2.1.4 of this article.
} 
as being rather more a rule of institutional conduct and less a principle of EC law. ${ }^{26}$ De Burca has nevertheless described subsidiarity as being both a political and legal principle, and thus a general principle of EC law, although it is very much politically driven. ${ }^{27}$ Thus, it has been maintained that over the years, subsidiarity has become a 'fully-fledged legal principle', ${ }^{28}$ which the Court has analysed within its case law. However, the Working Group which dealt with this principle in the framework of drafting the Constitutional Treaty reaffirmed the "essentially political nature' of subsidiarity. ${ }^{29}$ It was even said that based on its legal dimension, subsidiarity 'will not, except at the margin, solve questions of competence but will structure them. ${ }^{30}$ Similarly, it has been maintained that subsidiarity is a concept 'moulded to suit virtually any political agenda' ${ }^{31}$ and that it functions as a 'paradigm' for political debate. ${ }^{32}$ The difficulties in concretely applying subsidiarity reside therefore in the fact it has a narrow legal dimension and the decision of the appropriate level of exercising a certain competence is finally left to the political arena.

The third line of vision in the literature projects two rationales as regards the function of subsidiarity. According to one interpretation, subsidiarity acts as a shield against EU powers. ${ }^{33}$ This view is connected to

\footnotetext{
26 See T Schilling, 'A New Dimension of Subsidiarity: Subsidiarity as a Rule and a Principle' (1994) 14 YEL 203-55, distinguishing between subsidiarity in the narrow sense of a legal rule and its broader political meaning as a constitutional value.

27 See de Burca (n 14) and de Burca (n 15).

28 M Petite, 'Subsidiarity in Practice; A view from within the European Commission' Record of the Subsidiarity Conference Sharing Power in Europe. Striking the Right Balance between EU and member state action, Thursday 17 November 2005, The Hague, The Netherlands 32.

29 It was acknowledged that '... subsidiarity was of an essentially political nature, implementation of which involved a considerable margin of discretion for the institutions (considering whether shared objectives could 'better' be achieved at European level or at another level), monitoring compliance ... should be of an essentially political nature and take place before the entry into force of the act in question[.]'. Conclusions of Working Group I on the Principle of Subsidiarity, Brussels, 23 September 2002, CONV 286/02 WGI 1. The Working Group has also confirmed the need for a reinforced mechanism: 'To take account of the primarily political nature of monitoring subsidiarity, it was important to link the possibility of appealing to the Court against violation of the principle of subsidiarity with the use by national parliaments of the early warning system proposed above. Recourse to judicial proceedings must be able to occur only in limited and probably exceptional cases, when the political phase has been exhausted without any satisfactory solution being found by the national parliament(s) involved.' See the full text at <http://gandalf.aksis.uib.no/ brit/EXPORT-EU-Constitution/Export-Document-CONV/CONV-286-02-09-23-EN/index.html> accessed 30 March 2008.

30 N Bernard, 'The Future of European Economic Law in the Light of the Principle of Subsidiarity' (1996) 33 CML Rev 665.

31 See Peterson (n 8) 132.

32 R Barents, 'Het subsidiariteitsbeginsel in het Hervormingsverdrag' (2007) 11 Netherlands Tijdschrift voor Europees Recht 256-57.

33 This view is upheld by Estella. See A Estella (n 10).
} 
the significance of subsidiarity as legally provided in the Treaty of Maastricht, which considerably increased the competences of the Union. The principle of subsidiarity was therefore perceived as a counterbalance - a tool to protect national competences and interests. On the contrary, according to the second interpretation, subsidiarity functions as a 'Janus face ${ }^{34}$ or a 'double-edged sword', ${ }^{35}$ as Member States can adopt a stricter or looser stand based on their interests and the level at which they want them to be achieved. This Janus-faced aspect of subsidiarity is suggested by the fact that the Amsterdam Protocol refers to subsidiarity as a 'dynamic concept' which shall respect 'the institutional balance'. Seen as such, subsidiarity allows Member States to create more Europe in some areas and less Europe in others, according to their interests and resources in managing particular policy aspects..$^{36}$ According to this second interpretation, subsidiarity functions therefore as a platform to decide which is the regulatory level that best suits the Member States in achieving their interests and mitigates the exercise of shared competences.

These stumbling blocks of subsidiarity created the view that 'technically the principle is difficult to operationalize. ${ }^{37}$ Its overall assessment highlights its limited practical significance when it comes to operationalisation based on its legal framework and therefore its limited usefulness in demarcating the exercise of competences between the EU and the Member States. ${ }^{38}$ It also highlights the shaded areas where the EU

\footnotetext{
34 See T Jeppesen, 'Subsidiarity: A Janus Head?' (1995) European Studies Discussion Paper No. 11/95, Odense University.

35 See J Golub, 'Sovereignty and Subsidiarity in EU Environmental Policy' (1996) 44 Political Studies 686-703.

36 In this view, it can be said that the decisions adopted at the level of the Council, and thus at the level of the Member States, within the second and third pillars are so far the ones closer to this meaning attributed to subsidiarity. Such an example is the Council Framework Decision (EC) on the European arrest warrant and the surrender procedures between Member States [2002] OJ L 190/1. Recital 7 in the preamble to this framework decision provides that 'Since the aim of replacing the system of multilateral extradition built upon the European Convention on Extradition of 13 December 1957 cannot be sufficiently achieved by the Member States acting unilaterally and can therefore, by reason of its scale and effects, be better achieved at Union level, the Council may adopt measures in accordance with the principle of subsidiarity as referred to in Article 2 of the Treaty on European Union and Article 5 of the Treaty establishing the European Community. In accordance with the principle of proportionality, as set out in the latter Article, this Framework Decision does not go beyond what is necessary in order to achieve that objective.' This act has been challenged for its validity before the ECJ, one of the allegations being its breach of the principle of subsidiarity. In case C Đ 303/05 Advocatten voor de Wereld [2007] ECRI-3633, the ECJ delivered its judgment on this issue and found no breach of subsidiarity, thus maintaining the act and, therefore, the Member States' will when adopting this farreaching decision.

37 P Syrpis, 'In Defence of Subsidiarity' (2004) 24 OJLS 323-34.

38 In the words of Micklitz, subsidiarity was 'a mere weapon of Member States to refute Community activities, dominating any [...] positive constructive element, which would
} 
decision-making process is left in terms of claims of power sharing and achievement of interests.

\subsubsection{Institutional practices}

The burden of complying with subsidiarity lies mainly with the European Commission as it holds the central role in proposing legislation. The Amsterdam Protocol on the Application of the Principles of Subsidiarity and Proportionality requires a motivation of compliance with these principles for any proposed Community legislation. ${ }^{39}$ The Commission has therefore the duty to publish the explanatory memoranda of the legislative acts in the Official Journal. Yet, it has been observed that the motivation which the Commission gives in the explanatory memoranda is not up to expectations and full attention is not being paid to subsidiarity. In the words of Wyatt, this is 'perfunctory attention'. ${ }^{40}$ At the moment of Maastricht, subsidiarity was seen as an opportunity to slow down the legislative function of the Commission. ${ }^{41}$ The Commission at that time reviewed its legislative proposals and withdrew the ones crossing the line of subsidiarity. ${ }^{42}$ Over time, it has also improved its consideration of subsidiarity. Within the Better Regulation action, the Commission developed guidelines for the explanatory memoranda, which have to be included in its legislative proposals. Since 2003, the Commission has been conducting impact assessments of envisaged legislative proposals, as new action to improve its policy making competence. ${ }^{43}$ In the framework of the 2007

mean, that Member States might have to support the Community in the development of adequate rules to achieve the objectives of the Community.' See HM Micklitz, 'The Maastricht Treaty, the Principle of Subsidiarity and the Theory of Integration' [1993] Lakimies (Finnish Law Review) 531.

39 Article 4 of the Protocol provides: 'For any proposed Community legislation, the reasons on which it is based shall be stated with a view to justifying its compliance with the principles of subsidiarity and proportionality; the reasons for concluding that a Community objective can be better achieved by the Community must be substantiated by qualitative or, wherever possible, quantitative indicators.'

40 D Wyatt, 'Subsidiarity - Is it too Vague to be Effective as a Legal Principle?' in K Nicolaidis and S Weatherill (eds), Whose Europe? National Models and the Constitution of the European Union (OUP, European Studies at Oxford, 2003) 5.

${ }^{41}$ See K Van Kersbergen and B Verbeek, 'Subsidiarity as a Principle of Governance in the European Union' (2004) 2 Comp Eur Politics 143-63.

42 This was, for example, the case with the directives on bathing and drinking water. Also, a directive on animal welfare in zoos was originally published in 1991 under OJ C249/14, and then withdrawn because of the subsidiarity principle, as contained in European Communities C Bulletin 12/1992, 18. In 1999, however, the Directive suddenly appeared again as Council Directive (EC) 1999/22 relating to the keeping of wild animals in zoos [1999] OJ L94/24.

43 According to the Commission, 'Impact assessment (IA) is a process aimed at structuring and supporting the development of policies. It identifies and assesses the problem at stake and the objectives pursued. It identifies the main options for achieving the objective and 
evaluation report on the impact assessment system, it has been suggested that 'the scope of application of the IA [impact assessment] system should be adapted to cover proposals with the most significant potential impacts or those that pose particular problems with a view to subsidiarity. ${ }^{144}$ Nevertheless, the Commission has clearly stated that 'impact assessment is an aid to political decision, not a substitute for it. It informs decision-makers of the likely impacts of proposals, but it leaves it up to them to take the decisions. ${ }^{45}$ Full protection of subsidiarity cannot therefore be expected from the Commission as this institution has taken the view that although it has application in law, subsidiarity is an 'essentially political principle'. ${ }^{46}$

The decision on subsidiarity is left to interinstitutional interaction in the political arena. In this context, the Council ${ }^{47}$ and the Parliament ${ }^{48}$ are also obliged to observe compliance with the principle of subsidiarity as an integral part of the overall examination of the Commission's proposals. Although self-defined as the 'guardian of the principle of subsidiarity', ${ }^{49}$ the Committee of the Regions has limited influence on the decision-making process and in scrutinising the legislative proposals brought forward

analyses their likely impacts in the economic, environmental and social fields. It outlines advantages and disadvantages of each option and examines possible synergies and tradeoffs.' See Commission (EC), 'Impact Assessment' (Communication) COM (2002) 276, 5 June 2002.

44 Commission (EC), 'Better Regulation and enhanced Impact Assessment', (Information note from the President to the Commission), SEC (2007) 926, 28 June 2007.

45 See Commission (EC) 'Impact assessment guidelines' SEC(2005) 79115 June 2005 <http://ec.europa.eu/governance/impact/docs/key_docs/sec_2005_0791_en.pdf> accessed 30 March 2008.

46 Commission (EC), Communication on the principle of subsidiarity, Bull. EC 10, 1992, point 1. 1.4.

47 The European Council of Edinburgh emphasised the role that the Council plays in assuring subsidiarity due to its decisional powers among the EU institutions. See European Council (EC), Conclusions of the Presidency, Annex 1, Overall approach to the application by the Council of the subsidiarity principle and Article $3 \mathrm{~b}$ of the Treaty on European Union, Edinburgh 11 - 12 December 1992, 24.

48 Rule 34 of Parliament's Rules of Procedure states that '[d]uring the examination of a legislative proposal, Parliament shall pay particular attention to respect for fundamental rights and in particular that the legislative act is in conformity with the European Union Charter of Fundamental Rights, the principles of subsidiarity and proportionality and the rule of law.' See European Parliament, Rules of Procedure, $16^{\text {th }}$ edition, February $2008<$ http://www.europarl.europa.eu/sides/getDoc.do?pubRef=-//EP//TEXT+RULES-EP+200 80218+TOC+DOC+XML+VO//EN> accessed 30 March 2008.

49 See the Committee of the Regions (EC) 'Five questions, five answers' (Brochure) <http:// www.cor.europa.eu/pages/DetailTemplate.aspx?view=detail\&id=e955fa3e-b44c-483ca05a-851aca72acd0 > accessed 30 March 2008. For an overview on the activity conducted as regards the implementation and monitoring of the principle of subsidiarity, see Committee of the Regions (EC), The Committee of the Regions and the implementation and monitoring of the principles of subsidiarity and proportionality in the light of the Constitution for Europe (Office for Official Publications of the European Communities, Luxembourg 2006). 
by the Commission due to the fact that it can only act in an advisory capacity.$^{50}$ Nevertheless, its activity has added more input for highlighting the shortcomings in the application of the principle of subsidiarity. ${ }^{51}$ It is interesting to note that the Committee acknowledged the fundamentally political nature of subsidiarity, and the stance taken is that subsidiarity is a dynamic principle which can work both ways, either extending or limiting EU powers. ${ }^{52}$

\begin{abstract}
${ }^{50}$ Article 263 EC provides that 'A committee, hereinafter referred to as "the Committee of the Regions", consisting of representatives of regional and local bodies who either hold a regional or local authority electoral mandate or are politically accountable to an elected assembly, is hereby established with advisory status.' Article 265 EC provides that 'The Committee of the Regions shall be consulted by the Council or by the Commission where this Treaty so provides and in all other cases, in particular those which concern cross-border cooperation, in which one of these two institutions considers it appropriate.'

51 In 2005 the Committee of the Regions established a Subsidiarity Monitoring Network as a tool to exchange information between regional actors and proposals of the Commission which would impact on them. Within this framework, two tests were conducted in order to collect feedback from regional actors vis-à-vis four legislative proposals. The first test ran from 31 October until 9 December 2005 and involved 21 partners which were asked to prepare a subsidiarity/proportionality analysis of the two EC legislative documents, 'Thematic strategy on air pollution' (COM(2005) 446 final) and 'Proposal for a directive of the European Parliament and of the Council on ambient air quality and cleaner air for Europe' (COM(2005) 447 final)1.The second test ran from 6 October until 17 November 2006 and involved 49 partners which had to prepare an analysis, on the basis of the provisions of the Subsidiarity Protocol annexed to the Treaty of Amsterdam, of two EC legislative documents: 'Proposal for a recommendation of the European Parliament and of the Council on the establishment of the European Qualifications Framework for lifelong learning' (COM(2006) 479 final) and Communication from the Commission: 'Efficiency and equity in European education and training systems'(COM (2006) 481 final). In general terms, the analysis showed broad compliance with the principle of subsidiarity and proportionality of the acts included in the first test, while more criticism was given for the acts analysed within the second test. The suggestions of the tests referred, among other things, to the following: the need for better motivation by the Commission for compliance with the principle of subsidiarity in its legislative proposals; better impact assessments; better specification of the measures by means of which the Member States are requested to achieve certain objectives; and a strict application by the Commission of the Protocol on Subsidiarity and Proportionality, especially in areas where there are supporting political powers (such as Article 149 and $150 \mathrm{EC}$ ). For summaries with the conclusions of the two tests, see <http://www.cor. europa.eu/document/activities/Executive_Summary_EN.pdf.> accessed 30 March 2008 and <http://www.cor.europa.eu/document/activities/Report_2ndtest_CoR_Subsidiarity_ Network.pdf $>$ accessed 30 March 2008.
\end{abstract}

52 In one of its internal documents, it is stated that: 'Subsidiarity should be used as a dynamic tool that can create "more Europe" in some areas and "less Europe" in others, whilst always prioritising efficiency and the democratic representation of our co-citizen's interest.' Furthermore, it is added: 'It is important to remember that subsidiarity is a dynamic principle that works both ways. The aim of the subsidiarity principle is "better Europe". It should not be misused as a means of increasing public distrust towards the EU and what it does, which brings real added value in many areas.' See the position Committee of the Regions (EC), 'The application and monitoring of the subsidiarity and proportionality principles: The Committee of the Regions' political and operational role' (Bureau document) R/CdR 191/2006 item 8 fin, 2 August 2006

<http://cor.ip.lu/migrated_data/R_CdR_191_2006_item_8_fin.pdf> accessed 30 March 2008. 
It can be noticed from our analysis that subsidiarity functions as a principle of legal policy, deciding the level at which competences are exercised between the Union and the Member States. Such decisions are nevertheless politically guided. The principle of subsidiarity is therefore closely connected to the principle of interinstitutional balance, and the decisions on who should do what are interwoven in the EU law-making process in the institutional triangle: the Commission, the Council and the Parliament

\subsubsection{Judicial review}

So far we have discussed the application of the principle of subsidiarity at the ex ante law-making level. The ex post control regarding compliance of EU legislation with subsidiarity falls under the competence of the ECJ. On the introduction of subsidiarity as a principle of the Union, there were doubts as regards its judicial review by the Court. Toth argued that subsidiarity was justiciable only up to a certain point due to the limited nature of the Court's jurisdiction in cases involving judicial review of this aspect. ${ }^{53}$ This view was countered once the principle started to enter the ambit of the ECJ's case law. Hence, Dashwood observes that 'the justiciability of the principle cannot any longer be doubted'. ${ }^{54}$ It can therefore be said that subsidiarity is justiciable 'although not with mathematical certainty' ${ }^{55}$ The ECJ confirmed the justiciability of the principle of subsidiarity for the first time in the case United Kingdom v. Council ${ }^{56}$ and more explicitly in later cases. The Court found that compliance with the principle of subsidiarity is one of the conditions covered by the requirement to state the reasons for Community acts, under Article $253 \mathrm{EC}^{57}$, but it usually restricts itself to checking whether motivation has been provided within the preamble of the legal acts adopted. ${ }^{58}$ More substantive compliance with subsidiarity has been approached by the Court in only a few cases concerning the validity

\footnotetext{
53 AG Toth, 'Is Subsidiarity Justiciable?' (1994) 19 EL Rev 268-81. See also V Harrison, 'Subsidiarity in Article 3b of the E.C. Treaty-Gobbledegook or Justiciable Principle' (1996) 45 ICLQ 431,435.

54 A Dashwood, 'The Relationship Between the Member States and the European Union/ European Community' (2004) 41 CML Rev 368.

55 V Harrison, 'Subsidiarity in Article 3b of the EC Treaty: Gobbledegook or Justiciable Principle?' (1996) 45 ICLQ 431-439.

56 C-84/94 United Kingdom v. Council [1996] ECR I-05755.

57 See, for example, ECJ judgments in Case C-84/94 United Kingdom v. Council [1996] ECR I-5755 and Case C-233/94 Germany v. Parliament and Council [1997] ECR I-2405.

58 In defining the limits of this procedural control of subsidiarity, the ECJ held that the absence of an explicit reference to the principle of subsidiarity in the legal acts does not constitute a breach of the obligation to motivate, as long as there is a clear justification in the recitals that the aims of the measure can be best attained at Community level. Case C233/94 Germany v. European Parliament and Council [1997] ECR I-5755, para 26-28.
} 
of EU legislation. ${ }^{59}$ There has not yet been any judgment of annulment of an EU act due to breaches of the provisions on subsidiarity. ${ }^{60}$ Moreover, up to now subsidiarity has appeared only in a limited number of cases before the Court as a reason for asking for annulment or interpretation of EU legislation. ${ }^{61}$ The Court seems to be keeping a cautious approach due to the political sensitivity attached to the principle. Although it has been maintained that there is room for a more proactive approach, at least as regards procedural scrutiny, ${ }^{62}$ we cannot ask or expect from the Court what it is not due to deliver, that is, political decisions. ${ }^{63}$

Wrapping up, it can be said that there is not too much room left for ex post judicial review of EU legal acts based on compliance with subsidiarity. In the case law of the ECJ, subsidiarity has been only 'of little value as a standard of scrutiny'. ${ }^{64}$ Seen from a legal dimension, the overall picture of the judicial scrutiny of the principle of subsidiarity so far does not seem to shed light on how the exercise of powers is balanced between the Union and its Member States at the judicial law-making level.

\subsection{Subsidiarity in the Lisbon Treaty}

\subsubsection{Legal framework}

In the Lisbon Treaty, subsidiarity is mentioned as an EU principle in Article 5 of the Treaty on the European Union, which approximately restates the provisions of the current Article 5 EC. ${ }^{65}$ The novelty brought

\footnotetext{
59 See, for example, case C-377/98 Kingdom of the Netherlands $v$ European Parliament and Council [2001] ECR I-7079, case C-491/01 R v. Secretary of State for Health, ex parte: British American Tobacco (Investments) Ltd and Imperial Tobacco Ltd [2002] ECR I-11453 and cases C-155/04 and C-154/04 Alliance for Natural Health and Others [2005 ] ECR I-6451. The Court did not find a breach of subsidiarity since the measures proposed by the legal acts concerned the removal of obstacles to trade and distortion of competition in the internal market and were therefore easily justified as discussed by Wyatt. See D Wyatt and A Dashwood, European Union Law (Sweet and Maxwell, London 2006) 102-03.

60 The most far-reaching decision adopted by the Court in scrutinising the balance of powers between the EU and the MS is the British American Tobacco case, discussing the appropriate legal basis for adopting legislation, respectively Articles 94 and 95 EC. See Case C491/01 R v. Secretary of State for Health, ex parte: British American Tobacco (Investments) Ltd and Imperial Tobacco Ltd [2002] ECR I-11453.

61 According to Estella, this is due to the fact that the model subsidiarity case is that in which a Member State ... is outvoted [in the Council] and in turn brings an action of annulment against that measure on the ground of subsidiarity.' A Estella (n 10) 140.

62 See de Burca (n 15) 217-18.

63 In this line, Bermann favoured a rather procedural check of subsidiarity by the ECJ. See Bermann (n 7) 331-456.

64 C Ritzer, M Ruttloff and K Linhart, 'How to Sharpen a Dull Sword Đ The Principle of Subsidiarity and its Control' (2006) 7 German Law Journal 760.

65 According to Article 5 of the Treaty on the European Union, as amended by the Lisbon Treaty: 'Under the principle of subsidiarity, in areas which do not fall within its exclusive
} 
by Lisbon is the Protocol on the application of the principles of subsidiarity and proportionality, which contains a legal framework for a reinforced control of subsidiarity. ${ }^{66}$ This protocol opens up access to the European law-making process for national parliaments, which are given the role of controlling the compliance of legislative proposals with the principle of subsidiarity. Until now the ex ante protection of subsidiarity was left to the governments and their ability to defend the national regulatory competences. The new framework provides for an ex ante role for national parliaments. Let us recall the main provisions of the Lisbon Treaty defining the role of national parliaments to plead in this regard. ${ }^{67}$ As a first step, the EU institutions have to transmit their draft acts to the national parliaments, which will be entitled to send reasoned opinions within an eight week early warning system on the legislative proposals received. ${ }^{68}$ The EU institutions have to take account of the reasoned opinions issued by the national parliaments and, where non-compliance with the principle of subsidiarity represents at least one third of all the votes allocated to the national parliaments, the draft act must be reviewed. ${ }^{69}$ The institutions can decide to maintain, amend or withdraw the act and they have to give reasons for the decision. In the case of draft proposals issued within the ordinary legislative procedure, ${ }^{70}$ if the proposed legislative act is contested by a simple majority of the votes allocated to national parliaments,

competence, the Union shall act only if and insofar as the objectives of the proposed action cannot be sufficiently achieved by the Member States, either at central level or at regional and local level, but can rather, by reason of the scale or effects of the proposed action, be better achieved at Union level. The institutions of the Union shall apply the principle of subsidiarity as laid down in the Protocol on the application of the principles of subsidiarity and proportionality. National Parliaments ensure compliance with the principle of subsidiarity in accordance with the procedure set out in that Protocol.'

66 The Dutch government was particularly the one insisting on the introduction of an enhanced control of subsidiarity through the involvement of national parliaments. For details on the positions taken by the Member States' governments on the negotiation of the Lisbon Treaty, see V Miller, 'EU Reform: An Old Treaty or a New Constitution', (2007) Research Paper No. 07/64, House of Commons Library <http://www.parliament.uk/commons/lib/ research/rp2007/rp07-064.pdf > accessed 30 March 2008.

67 The relevant provisions on subsidiarity can be found in the text of the Lisbon Treaty and in three Protocols attached to it: Protocol on the role of national Parliaments in the European Union, Protocol on the application of the principles of subsidiarity and proportionality, Protocol on the exercise of shared competence. The text of the Lisbon Treaty is available on line at <http://eur-lex.europa.eu/JOHtml.do?uri=OJ:C:2007:306:SOM:EN:HTML > accessed 30 March 2008.

68 According to the Lisbon Treaty, the legislative proposals can originate from EU institutions or a group of Member States. See the relevant provisions of the Protocol on the Application of the Principle of Subsidiarity and Proportionality, Articles 3-6.

69 Article 7, paragraph 2 of the Protocol: 'This threshold shall be a quarter in the case of a draft legislative act submitted on the basis of Article $61 \mathrm{I}$ of the Treaty on the Functioning of the European Union on the area of freedom, security and justice.'

70 This is co-decision. 
the Commission will have to review the respective act. The Commission can maintain, amend or withdraw the act. If maintained, the Commission will have to give a reasoned opinion for its decision. In such a case, the Council and the Parliament will have to consider the reasoned opinion of the Commission and those of the national parliaments within a special procedure and decide on compatibility with the principle of subsidiarity. The legislative proposal considered under this procedure can be rejected for incompatibility with the principle of subsidiarity only with a majority of 55 per cent of the members of the Council and a majority of the votes cast in the European Parliament. The ex post protection of subsidiarity is left to the competence of the European judiciary, which will be empowered to hear cases alleging breaches of subsidiarity. Such actions can be introduced by the Committee of the Regions or by the Member States on behalf of their national parliaments. As a consequence, the effect of the new framework on subsidiarity will depend at last resort on the stance taken by the ECJ as regards the legal review of this principle. ${ }^{71}$

\subsubsection{Interpretation and criticism}

By strengthening the control on subsidiarity, the new mechanism provided by the Lisbon Treaty seems to intend an increased scrutiny of this principle. The weak ex post control of subsidiarity has been reinforced with an ex ante one. ${ }^{72}$ The essential added value of the new protocol is the association of the national parliaments in the process of lawmaking at EU level. One author argued that it is indeed for the national parliaments to take an active role, as '...national Parliamentarians are the ones whose law-making powers are liable to be curtailed by a decision that a certain matter be regulated at the Union level, so they ought to be alert to possible infringements of the principle' ${ }^{73}$ Nevertheless, there has been criticism in the literature as regards the real power of scrutiny which national parliaments will have. It has been argued that the influence which national parliaments are expected to have is a limited one and '...we should be very careful not to expect national parliaments, or, more, accurately, parliamentary majorities, to turn suddenly and pub-

\footnotetext{
${ }_{71}$ For Koopmans this is a reason to fear that the principle of subsidiarity will be depoliticised and considered as a rather technical and legal aspect, instead of a matter of policy, which in his view would increase the gap between citizens and politicians, as the former want more visible political implication. See T Koopmans, 'Subsidiarity, Politics and the Judiciary' (2005) 1 European Constitutional Law Review 112-16.

72 That is why some authors maintain that subsidiarity came back in force in the Constitutional Treaty. See PA Feral, 'Retour en force du principe de subsidiarité dans le traité constitutionnel: de nouvelles responsabilités pour les parlements nationaux et pour le comité des régions' (2004) 481 Rev Marche Com 496-99.

73 Dashwood (n 57) 368
} 
licly into assertive and powerful policy influencers in the EU affairs. ${ }^{74}$ In this line, when analysing the role of national parliaments in European matters, Raunio concludes that most national parliaments are not suitably equipped to scrutinise EU legislation..$^{75}$ The framework for national parliaments' involvement is also criticised by Weatherill as being only a limited power attributed to them. ${ }^{76}$ A true assessment of compliance with subsidiarity would imply giving technical expertise on substantive aspects, and the period prescribed in the Protocol does not allow enough time in this respect. The eight week timetable and the difficulty of knowing the views of other national parliaments have been put forward within a test run in the framework of the Conference of Community and European Affairs Committees of Parliaments of the European Union (COSAC) as regards the early warning mechanism proposed in the Constitutional Treaty. ${ }^{77}$ Currently, the subsidiarity check included in the Lisbon Treaty is also being tested. ${ }^{78}$

Moreover, broadly speaking, subsidiarity is not just an eight-week issue, but a continuous one, as it relates to the balance of powers between the Union and its Member States, and to the continuous disposal of interests. It may be said therefore that more efficient control of the content of the legislative proposals could be done during the pre-formal negotiation process in the Council when views from the national parliaments could be upheld by the government representatives; before having a draft proposal, national parliaments could influence their governments to negotiate and scrutinise in a certain way, as at a formal level it is more

\footnotetext{
74 K Auel, 'Democratic Accountability and National Parliaments: Redefining the Impact of Parliamnetary Scrutiny in EU Affairs' (2007) 13 ELJ 487-504. In the same line, see also the analysis in S Weatherill, 'Better Competence Monitoring' (2005) 30 EL Rev 23-41.

75 Two improvements are suggested: national parliaments need more resources in order to deal with EU matters, and the scrutiny of subsidiarity should be extended to all specialised standing committees, not only to the ones explicitly in charge of EU affairs. These improvements would have an important role in acquiring expertise in EU affairs. See T Raunio and M Wiberg, 'Does Support Lead to Ignorance? National Parliaments and the Legitimacy of European Governance' (2000) 35 Acta Politica 146-68.

76 S. Weatherill, 'Using National Parliaments to Improve Scrutiny of the Limits of EU Action' (2003) 28 EL Rev 909-12.

77 See Report on the results of COSAC's pilot project on the $3^{\text {rd }}$ Railway Package, testing the subsidiarity early warning mechanism <http://www.cosac.org/en/info/earlywarning/ pilotproject/pilot/> accessed 30 March 2008.

78 The test is conducted within COSAC for the Council Framework Decision amending Framework Decision 2002/475/JHA on combating terrorism COM(2007) 650 final. More details about the test can be found at <http://www.cosac.eu/en/info/earlywarning/Test/ reldoc/pdf/> accessed 30 March 2008. More information about the role of COSAC in monitoring the principle of subsidiarity was presented by Lord J Grenfell, 'Subsidiarity and COSAC' in Record of the Subsidiarity Conference Sharing Power in Europe. Striking the Right Balance Between EU and Member State Action, Thursday 17 November 2005, The Hague, The Netherlands 53-58.
} 
likely that the subsidiarity test will only be able to answer whether the procedural criteria have been met.

Several other aspects add to the view that the new role attributed to national parliaments will be a difficult one. As yet, there have been no fully, formally established structures at the level of national parliaments responsible for the control of subsidiarity. ${ }^{79}$ As a result, one of the problems raised by the new framework relates to aspects of coordination. It has also been said that '[the] introduction of the ex-ante system could undermine efforts to enhance the efficiency of EU decision-making, since national parliaments consultation would need to be co-ordinated and overseen. ${ }^{80}$ This critique translates into the fear that the mechanism for controlling subsidiarity could hinder the European integration process. Furthermore, it has been observed that a conflict might arise between the positions adopted by the national parliaments when checking subsidiarity and the positions held by the corresponding governments in the Council. ${ }^{81}$ The political architecture and representation at national level will thus play an important role.

As afore-exemplified, although not yet in force, the new role attributed to national parliaments in the ex ante scrutiny of subsidiarity has already received a lot of criticism in the literature. Kiiver even concluded that '...putting false hopes in the national parliaments would mean to accept far less than what we are entitled to in terms of representative democracy in the European Union. ${ }^{182}$ As drafted in the Lisbon Protocol, subsidiarity seems to have followed again the shield rationale, as intended at its introduction in the Maastricht Treaty. Nevertheless, it remains to be seen how national parliaments will make use in practice of their scrutiny powers. ${ }^{83}$

\footnotetext{
79 An overview of the foreseen models for the early warning mechanism in 25 national parliaments can be found at <http://www.cosac.eu/en/info/earlywarning/overview/ > accessed 30 March 2008.

80 P Beyer and others, 'The Draft Constitution for Europe and the Environment' (2004) July European Environmental Law Review 223. This relates to fears that the procedure will 'politicise and indeed polemicise [...] in ways which are counterproductive for the European legislative process'. See F Amtenbrink, Continuation or Reorientation. What Future for European Integration? Erasmus Law Lectures 9 (Boom Juridische uitgevers, Den Hague 2007) 34-35.

81 See for example discussions in A Follesdal, 'Subsidiarity, Democracy, and Human Rights in the Constitutional Treaty of Europe' (2006) 37 Journal of Social Philosophy (J Soc Phil) 61-80; I Cooper, 'The Watchdogs of Subsidiarity: National Parliaments and the Logic of Arguing in the EU' (2006) 44 JCMS 281-304; and P Kiiver, The National Parliaments in the European Union: A critical View in the EU Constitution-Building (European Monographs, Maastricht 2005) 154-58.

82 P Kiiver above.

83 The stance taken by national parliaments might depend in part on the internal political architecture of every Member State.
} 
The Lisbon Treaty also reinforces the ex post control of the principle of subsidiarity. The Committee of the Regions is offered the right to introduce actions for the annulment of 'legislative acts for the adoption of which the Treaty on the Functioning of the European Union provides that it be consulted', ${ }^{84}$ if it considers that a certain act is breaching subsidiarity. Moreover, national parliaments will have an indirect right to introduce actions on grounds of infringement of the principle of subsidiarity via their national governments. ${ }^{85}$

Although not containing an exhaustive list of criteria, it can be said that the Amsterdam protocol gave more guidance in applying subsidiarity than the Lisbon protocol, as some of these criteria have not been kept in the latter. This choice might be motivated by the fact that since Amsterdam the Commission has developed its impact assessment process, defining more specific criteria for applying the principle of subsidiarity. Another element of novelty in the Lisbon Treaty is that there is a clearer demarcation of competences. ${ }^{86}$ Nevertheless, problems might still arise due to their special content and phrasing in several policy areas. ${ }^{87}$ It can be observed that in the Lisbon Treaty subsidiarity continued to focus on questions of competences and not sufficiently on questions of content and policy lines. One author even claimed that '[s]ubsidiarity remained the vague and elusive norm it has always been'. ${ }^{88}$ Yet, the importance of this new legal framework has been acknowledged, especially as regards its contribution towards reducing the democratic deficit of the Union. ${ }^{89}$ Moreover, the control mechanism for subsidiarity, although not having real power of scrutiny, might act towards raising the awareness of EU institutions that they should pay due attention to subsidiarity as it will be exposed to a broader assessment. It can therefore be suggested that the new legal framework might help towards increasing the culture of subsidiarity at the level of EU institutions. ${ }^{90}$

\footnotetext{
84 These areas are: economic and social cohesion, trans-European infrastructure networks, health, education, culture, employment policy, social policy, the environment, vocational training and transport.

85 It remains to be seen whether national governments are willing to act on behalf of their national parliaments, especially in those cases in which the governments voted in favour of a particular legislative act within the decision-making process in the Council.

${ }^{86}$ The Treaty provides a catalogue of competences, divided into exclusive, shared and supporting, coordinating and supplementing competences.

87 See, for example, the relevant provisions in the Lisbon Treaty under the amendments introduced to the EC Treaty, Articles 2C, 2D, 18 B, 42.

88 See Kersbergen and Verbeek (n 41) 233.

89 See I Cooper, 'Subsidiarity to the Rescue: Why the 'Early Warning System' Should be Salvaged from the Constitutional Treaty' (2005) 40 Intereconomics 185-91.

90 It can be said that over the years, the Commission started to develop a certain culture for subsidiarity which is reflected in instruments such as better regulation reports, impact assessments, etc, and that the Commission is more inclined to take account of subsidiarity if it wants its pieces of legislation to be adopted.
} 


\subsection{Intermediary conclusions}

The aspects analysed show that subsidiarity is a concept full of meaning. But, as stated by Bermann, subsidiarity 'must not only mean something; it must matter'. ${ }^{91}$ To wrap up, it can be said that subsidiarity has proved so far to be only of limited value in understanding how powers are balanced between the EU and its Member States. Furthermore, in the Lisbon Treaty there are still shortcomings in the legal construction of subsidiarity. If seen as a shield against EU legislation, the legal framework of subsidiarity cannot perform a function of fully fledged legal protection for national powers in the process of exercising the competences shared between the EU and its Member States..$^{92}$ Likewise, if subsidiarity is seen as a double-edged sword, its legal framework does not provide us with full understanding of how the principle is operationalised in practice. The lack of clear criteria, in the current and future Lisbon legal framework of subsidiarity, for delimiting when the exercise of a certain competence lies with the Union and when with the Member States increases the opacity of the EU decision-making system. One might argue that new adjustments to the legal framework need to be made. These adjustments would depend on a further function desirable for subsidiarity: more shield protection or a dynamic double-edged sword interaction? Due to its mainly political character, it is hard to envisage a tight legal framework for subsidiarity. Furthermore, given the long and hard political road which had to be climbed up to Lisbon, it is less probable that other treaty amendments will soon see the light. ${ }^{93}$

The analysis made, together with the criticism presented, does not intend to suggest that the existence of subsidiarity as a guiding principle of the Union is useless. Likewise, neither a denial nor an undervaluation of its legal and political significance is implied. Given the fact that there is no Kompetenz-Kompetenz for the Union, the non-inclusion of subsidiarity among its guiding principles would mean leaving the exercise of competences somehow in a legal vacuum. Moreover, its role in diminishing the democratic deficit of the Union is also accepted. Subsidiarity 'is a

\footnotetext{
$91 \quad$ See Bermann, (n 7) 337.

92 Although it was introduced with high expectations, the reality check showed that it does not yield real power of watching over the integrationist development of the Union. In this view, Marquardt states that 'just because subsidiarity provides a check on integration does not mean that it is protective of national prerogatives.' See PD Marquardt, 'Subsidiarity and Sovereignty in the European Union' (1994) 18 Fordham Intl L Rev 639. The same approach is taken by Feral when stating that subsidiarity protects insufficiently the Member States against 'l'expansionnisme' of the EU. See PA Feral, 'Le principe de subsidiarité après la signature du traité établissant une Constitution pour l'Europe,' (2004) 38 Actualité juridique. Edition droit administratif 2085-93.

93 This does not exclude however the possibility to adopt secondary legislation.
} 
good objective to have' ${ }^{94}$ Nevertheless, its practical efficiency in controlling the balance of powers between the Union and the Member States is limited. ${ }^{95}$ The main question remaining is by whom and how is the exercise of shared competences decided in the daily interaction between the EU and its Member States? Only by shedding more light at this level will there also be better understanding of the way in which the balance of powers between the two legal orders is maintained in every day work. Seen through the lens of its legal framework, subsidiarity does not prove to be a very useful principle in this regard; it tends to work as a principle for structuring the political discourse instead of functioning as an instrument for operationalising the exercise of competences and the protection of national interests in the EU. What is then to be done? A change of perspective might provide greater understanding of how this balance is maintained in practice.

\section{Beyond subsidiarity. Perspectives for future legal research.}

\subsection{Research approach}

The review of subsidiarity in the previous section revealed that so far the demarcation of competences between the EU and the Member States has been mainly discussed with reference to the principles of attribution and subsidiarity. This has shaped a rather theoretical and abstract approach, which considers the demarcation of powers in the EU from a top-down perspective. But subsidiarity is not only an ideological concept in the EU; it is also an institutionalised instrument. This is why there is a need to look at the interinstitutional interaction during the law-making process, and not only at the final outcome which is scrutinised in terms of subsidiarity. Attention is drawn here to investigating the process beyond the legal framework of subsidiarity which might shed more light on how the balance of powers between the two legal worlds is maintained in practice. In this view, this part of the article proposes a change of perspective by looking at the daily interaction between the two legal worlds and at how the frictions between them are resolved in practice. This translates into a more practical bottom-up approach.

\footnotetext{
94 L Tsoukalis, 'The Politics and Economics of Subsidiarity' in Record of the Subsidiarity Conference Sharing Power in Europe. Striking the Right Balance between EU and Member State Action, Thursday 17 November 2005, The Hague, The Netherlands.

95 It was said that subsidiarity operated 'as an ambiguous norm, primarily offering a standard of behaviour for legitimate legislative action.' See K Van Kersbergen and B Verbeek, 'The Politics of International Norms: Subsidiarity and the Imperfect Competence Regime of the European Union' (2007) 13 Eur J Intl Rel 224-25.
} 


\subsection{Hypothesis and aim}

The criticism attributed to subsidiarity and the stated approach of future research suggest that another theory may have more explanatory potential for understanding the actual balance of power between the EU and its Member States and for defining the scope for legitimate protection of national interests. In this context, the following hypothesis is put forward: the competences between the EU and the Member States are demarcated in daily practice by negotiating and balancing national discretionary powers, rather than defined through the legal framework of subsidiarity.

One aim of future research would be to chart the use of discretionary powers for protecting national interests in order to explain how competences between the two realms, the EU and its Member States, are balanced in practice in the law-making process. A second aim would be to assess the normative reliance on and efficiency of the discretionary powers left to the Member States in the law-making process as a tool for protecting national interests and reconciling the national and European legal orders. It is to this end that an approach beyond subsidiarity is proposed as a follow-up of the analysis made in part 2 of this article.

\subsection{One level of analysis and three perspectives}

From a vertical perspective, research beyond subsidiarity would analyse the use of discretionary powers at the level of the EU law-making framework. ${ }^{96} \mathrm{~A}$ broad understanding would be adopted for law-making, covering legislative action and judge-made law. Two practical research perspectives are proposed for this view. The first one concerns an analysis of the ex ante law-making process in the EU in order to assess the room for manoeuvre left to the Member States in protecting their national competences and interests. More specifically, it concerns the use of national discretionary powers in the negotiation process which leads to the adoption of EU legislation. The second practical perspective concerns an ex post protection of national interests as occurring at the level of the European judiciary in the process of balancing national discretionary powers. A third perspective regarding the concepts of discretion, interests and unity would underlie and connect the two practical perspectives. Several general arguments, drawn forth by reviewing existing research or based on this author's own assessment will be offered in order to motivate the choice of the three perspectives and to substantiate their operationalisation throughout the proposed research.

96 At national level, discretion is at stake at national level when implementing EU legislation, more specifically EU directives, which leaves to the Member States the choice of the means to reach the desired goal. 


\subsubsection{Ex ante law-making}

Since national interests are represented in the EU institutional architecture at the level of the Council, this institution will therefore be our platform for analysis. In today's EU institutional architecture, the Council still holds the central position in the law-making process, although in the majority of areas it shares this power with the European Parliament within the co-decision procedure. ${ }^{97}$ The importance of this institution in the EU law-making process has been extensively acknowledged in legal and political sciences literature. ${ }^{98}$ Its role has been highlighted not only as regards formal aspects of the institutional mechanism for decisionmaking, but also in connection to the process taking place beyond the formal rules. At the very initial stage of the European Communities, Haas pointed out the importance of people's perceptions and attitudes for the cooperation process, underlining the difference between formal agreement and the real power structure. ${ }^{99} \mathrm{He}$ drew attention to the importance played by the Council within the integration process, observing that:

It is impossible to assess the role of the Council in European integration merely...on the basis of treaty texts. If the operational code habitually employed by the people who compose the Council can be demonstrated to result in further integration, then plainly the general level of argumentation described [in treaty texts] is beside the point. ${ }^{100}$

The focus of future research should be placed on a less visible institutional actor, but which holds a key position within the Council. Designed as a body to support the work of the Council, as provided for in Article 207 EC, Coreper plays at present a de facto role in the EU lawmaking process. It functions as an intermediary between the national governments and the EU institutions. The importance of this committee has not yet been sufficiently acknowledged in the existing legal literature and there is a clear need for more and renewed study of its functioning due to the fundamental changes in the legal and political spectrum of the Council with the last accessions, and to the novelties introduced by the

\footnotetext{
${ }_{97}$ With the Lisbon Treaty, co-decision will become the ordinary procedure for decisionmaking.

98 As regards the principle of subsidiarity in connection to the Council, Hix is of the opinion that '...subsidiarity should relate to a check on the national governments far more than a check on the Commission'; 'where the Member States have common interests and common preferences they are much happier to pass vague legislation and give each other a lot of discretion on how they implement the law.' See S Hix, 'Subsidiarity in Today's EU: appropriate and legitimate' in Record of the Subsidiarity Conference Sharing Power in Europe: Striking the Right Balance between EU and Member State Action, Thursday 17 November 2005, The Hague, The Netherlands, 43.

99 See E Haas, The Uniting of Europe (Stanford University Press, Stanford 1958).

100 E Haas, Beyond the Nation State (Stanford University Press, Stanford 1964).
} 
Treaty of Lisbon. Since its early establishment Coreper was designed as a body to support the work of the Council. ${ }^{101}$ Gradually, it developed more and more decision-making power. ECJ clarified the role of Coreper in the decision-making process by interpreting the provisions of Article 207. ${ }^{102}$ It stated that the de jure power rests with the Council. ${ }^{103}$ Nevertheless, the de facto role of Coreper in the decision-making process at Council level has been acknowledged in practice and in the literature. ${ }^{104}$ This has mainly been argued on the basis of the A-points practice, where decisions are already taken at the level of Coreper and there is only a formal approval in the Council. At present, Coreper is a key player in the everyday decision-making process. This is due on one hand to the peculiar features of its own institutional setting and internal functioning, and on the other hand to the fact that this body operates within the bigger institutional architecture of the EU, at the crossroads of the main decisionmaking actors: the European Commission, the European Parliament and the Council. So far, Coreper has been the object of study of several articles and book chapters, and even a limited number of books are entirely or partly dedicated to this EU body. ${ }^{105}$ Nevertheless, legal scholarship has not yet fully acknowledged the importance of this body. The most discussed aspects in the literature regard the following: the negotiation process undertaken at this level; the decision-making process in a rather broad context and the underlying issue of efficiency; delegation and the role of bureaucrats. Less attention is given to aspects of political accountability, to specific decision-making procedures, such as co-decision, and to the effect of the political process on legal outcomes. Moreover, most of

\footnotetext{
101 For a history of the first decade of the functioning of Coreper, see NP Ludlow, "Mieux que six ambassadeurs. L'emergence du COREPER durant les premières années de la CEE' in L Badel (ed), Les administrations nationales et la construction européenne: une approche historique (1919-1975) (Bruxelles, 2005).

102 Article 207 EC provides that: 'A committee consisting of the Permanent Representatives of the member States shall be responsible for preparing the work of the Council and for carrying out tasks assigned to it by the Council. The Committee may adopt procedural decisions in cases provided for in the Council's Rules of Procedure'.

103 In case C 25/94, Commission of the European Communities v. Council of the European Union, 19 March 1996, the ECJ held that Coreper is only an auxiliary body of the Council, for which it carries out preparation and implementation work, and not an institution with decision-making powers on its own. For a full explanation, see para 21-28 of the judgement. For a comment on this case, see N Burrows, 'COREPER, Competence and Conservation' (1997) 22 (1) EL Rev 64-67.

104 This finding is mainly based on empirical research. See, for example, J Lewis, 'Is the "Hard Bargaining" Image of the Council Misleading? The Committee of Permanent Representatives and the Local Elections Directive' (1998) 36 (4) Journal of Common Market Studies 481.

105 See the articles further mentioned in this paper and the following books: JW De Zwaan, 'The Permanent Representatives Committee: Its Role in European Union Decision-Making' (1995) TMC Asser Instituut; V. Constantinesco, D. Simon (eds), Le COREPER dans tous ses etats, (Presses Universitaires de Strasbourg, Strasbourg, 2001).
} 
the literature on Coreper takes a social and political sciences approach and less a legal one. In a recent rich empirical study, Larue concludes that additional research on both the roles and power of the bureaucrats working in Brussels is necessary. ${ }^{106}$ For Lewis, the community method is "partially produced and maintained through the institutional channel of Coreper'. ${ }^{107}$ This body is also the most relevant one for examining how national interests advocate in the EU decision-making process. ${ }^{108}$

The present context offered by the changes introduced by the Lisbon Treaty, as well as in view of the past enlargement and future prospects, together with its specific institutional features, makes Coreper a relevant context to study the use of discretionary powers for the protection of national interests in the ex ante EU law-making process. For the purpose of the proposed research, Coreper would therefore be employed as a barometer for assessing the use of national discretionary powers. Since it operates very much out of sight, its actual influence on the decisionmaking process in the EU could therefore be made more visible in future research.

\subsubsection{Ex post law-making}

The second perspective proposed for an approach beyond subsidiarity targets the ECJ as a relevant context for performing the research. The role played by the Court in the EU's constitutionalisation has already been widely acknowledged in the literature. The barometer for testing the use of discretionary powers would here be the principle of proportionality, which represents a more efficient criterion for assessing the balance between the powers of the EU and those of the Member States. On proportionality, the Court has engaged into a much more solid case law. Since subsidiarity is dependent on proportionality as regards the kind of action envisaged, it has been suggested by Davies that it is a more suitable criterion for assessing the exercise of competences. ${ }^{109}$ The principle

\footnotetext{
106 See T Larue, 'Agents in Brussels: Delegation and democracy in the European Union' (Doctoral Thesis, Umeå: Faculty of Social Sciences, Political Science 2006). This PhD thesis explores the delegation between bureaucrats in Brussels and governments in Member States' capitals and concludes that additional research is necessary on both the roles and power of the bureaucrats working in Brussels: 'Another future project ... would be to link the interest for national bureaucrats stationed in the member countries' permanent representations and expand the assessment of their roles within the EU system of policymaking in Brussels.'

107 J Lewis, 'Is the "Hard Bargaining" Image of the Council Misleading? The Committee of Permanent Representatives and the Local Elections Directive' (December 1998) 36 (4) Journal of Common Market Studies 486.

108 J Lewis, 'National Interests: Coreper' in J Peterson, M Shackleton (eds), The Institutions of the European Union ( $2^{\text {nd }}$ edn Oxford University Press 2006) 282.

109 G Davies, 'Subsidiarity: The Wrong Idea, in the Wrong Place, at the Wrong Time' (2006)
} 
of proportionality is an easier point of assessment as it observes that the burdens of a certain action will not be disproportionate to the objectives of the Community.

At the level of ECJ law-making, discretion is left to the Member States when invoking the grounds of derogation provided by the Treaty, for example in the area of the internal market. ${ }^{110}$ An in-depth analysis of the discretion left by the Court to the Member States when assessing compliance with EU legislation vis-à-vis the application of the principle of proportionality would therefore build towards a better understanding of how the competences are balanced between the European and national realm; it would consequently show how the interests are being reconciled at this level.

\subsubsection{Conceptual interplay}

In light of the stated hypothesis, the dual aim and the level of analysis, the ex ante and ex post perspectives of law-making in the EU would be underlined by a conceptual perspective on discretion, interests and unity. In the context of the proposed research approach, discretion would be understood as the residual competences that legal rules leave to agents in the framework of the EU law-making process. The concept of interests, in connection to state agents, would be defined as the balanced alternatives between pure preferences, and the political and legal constraints present in the reality of the EU law-making process. Unity is understood here as the coherence and consistency of the EU law-making mechanism, which offers a unique framework for achieving national interests at a collective level. Future specific research would employ these concepts as an analytical tool for answering the following question: how can Member States protect national interests through the use of discretionary powers in daily practice in the framework of EU law-making unity?

\subsection{Methodology}

The research approach proposed in this article would be mainstream legal research. Nevertheless, it would strike an interdisciplinary note when connected to philosophy within the conceptual perspective or political sciences in dealing with the functioning of Coreper, which would mainly be empirically driven. The novel perspective would be offered by drawing

\footnotetext{
43 CML Rev 63-84.

110 These grounds refer to aspects of public morality, public policy, public security, public health, the protection of health and life of humans, animals or plants, the protection of national treasures possessing artistic, historic or archaeological value, or the protection of industrial and commercial property. See the relevant provisions in Articles 30, 46, 55 and 58 of the EC Treaty.
} 
the analysis through the lens of discretion, a concept which would be transversally analysed in the context of EU law-making.

\section{Final concluding remarks}

It has been shown throughout the analysis made in this article that subsidiarity has been extensively analysed in the specific EU legal literature. Despite this academic attention, the reality check has showed its low efficiency in achieving one of its envisaged roles: protecting national powers and interests. In this view, subsidiarity has been perceived as a 'busted flush', ${ }^{111}$ a 'fig leaf ${ }^{112}$ or even as 'the wrong idea, in the wrong place, at the wrong time'. ${ }^{113}$ Moreover, the legal framework of subsidiarity, developed through several EU Treaties, including the future Lisbon Treaty, fails to provide a clear understanding of how the principle is being considered in the EU decision-making process. These shortcomings are doubled by the cautious and marginal approach which the ECJ has taken so far in reviewing subsidiarity. It is in this context that this article proposes an approach beyond subsidiarity for future research. This approach would conduct a bottom-up analysis to make sense of the way in which competences between the EU and its Member States are demarcated in daily interaction. It is proposed to make an analysis of the way national discretionary powers are used in the EU law-making process to protect national interests. Two levels of analysis have been more specifically identified: an ex ante one, when negotiating and adopting EU legislation, and an ex post one, when the ECJ balances the interaction between the EU and its Member States by employing the principle of proportionality. By assessing the use of discretionary powers as a tool for protecting national interests, future research might shed more light on how the two legal worlds are reconciled in the law-making process.

\footnotetext{
111 M Stewart, 'Subsidiarity: A Busted Flash?' in D O’Keeffe and PM Twomey (eds), Legal Issues of the Maastricht Treaty (Chancery/Wiley, Chichester/Colorado Springs 1994).

112 N Emiliou, 'Subsidiarity: Panacea or Fig Leaf' in Keeffe and Twomey (n 111) 65.

113 G Davies (n 109).
} 